\title{
Structure and evolution of the Gulf of Lions: The Sardinia seismic experiment and the GOLD [Gulf of Lions Drilling] project
}

\author{
D. Aslanian, M. Moulin, P. Schnurle, F. Klingelhoefer, and E. Leroux, Ifremer, Centre de Brest \\ M. RABINEAU, IUEM \\ A. GAILLER, CEAF \\ F. BACHE, GNS Science \\ C. GorINI, Paris VI University \\ J. Kuroda and N. EGuchl, Japan Agency for Marine Earth Science and Technology \\ A. DroXLER, Rice University \\ K. ALAIN, LM2E \\ F. RouRE, IFP Energies Nouvelles \\ B. HAQ, National Science Foundation, USA
}

T he study of the deep structure and evolution of passive continental margins is important for the understanding of rifting processes and the formation of associated sedimentary basins. Since the classical models of McKenzie (1978) and Wernicke (1985), understanding how passive continental margins form, that is to say mainly the way that continental lithosphere is thinned leading to subsidence, remains one of the main challenges in the Earth sciences. Many recent observations and discoveries have modified our basic views of margin formation. The conservational models paradigm (i.e., simple shear, pure shear, or polyphase models), which exclude exchanges between lower continental crust and upper mantle and which are usually proposed to explain lithospheric stretching and consequent crustal thinning of passive continental margins, fail to completely explain all these observations. Furthermore, these models imply a large amount of horizontal movement, movements not observed in the field. In consequence, new concepts need to be built and tested.

One of the main obstacles to our understanding of margin formation is the unknown nature of the transitional domain between the unthinned continental crust and the true oceanic crust. Using paleogeographic constraints, wide-angle refraction seismic and $2 \mathrm{D}$ reflection seismic profiles or modeling, some authors suggested that lower continental crust may have been removed from its original place and flowed toward the middle part of the system (allochthonous domain, part 2 in Figure 1) or/and toward both extremities of the conjugate margins system (Aslanian et al., 2009; Huismann and Beaumont, 2011; Aslanian and Moulin, 2012).

Another challenge is to understand how margins evolve starting in a structurally elevated position during initial formation, with the presence of subaerial deposition of basalts, shallow-water evaporites, subaerial erosion, and/or construction of a carbonate platform, toward a basin affected by strong subsidence during the plate divergence phase. Passive margins seem to be close to sea level, even after the breakup as demonstrated by carbonates postdating the oceanic crust (e.g., on the central and the south Atlantic margins). We therefore need to be able to reconstruct the paleo-water depth at the time of the deposition of the syn-rift and post-rift sediments.

\section{The Gulf of Lions: A unique natural laboratory}

The Gulf of Lions (Figure 2) represents a unique natural laboratory to study both evolution and interaction of deep processes (geodynamics, tectonics, subsidence, isostasy) and more superficial processes (river behavior, sedimentary fluxes, sea-level changes, climate change, etc.) because of certain characteristics:

- The Gulf of Lions represents a segment of a continental margin which is both young (less than $35 \mathrm{Ma}$ ) and has a low continental slope gradient (less than $1^{\circ}$ ). This allows a detailed observation of its structure and thus quantitative analysis of its significant (up to $7.7 \mathrm{~km}$ ) sedimentary cover (because of a small amount of instabilities); and its conjugate margin, the Sardinia margin, is equally accessible. Having a conjugate margin pair contained in a relatively small area is a rare situation and therefore it offers a unique opportunity to validate models of continental breakup and subsidence evolution.

- The sedimentary series are continuous and complete, neither affected by substratum tectonics nor by recent tectonics or gravity processes (Figure 3). Interpretation of sediment strata provides therefore three kinds of information: information on paleoclimatic history, information on the tectonic history of the margin (vertical movements), and finally, as correlations are possible all along the margin, it allows for a precise evaluation of the sedimentary fluxes and erosion/sedimentation balance.

- The time span of the basin (30 Ma) records some key events in climate evolution. Cenozoic records indeed show a global drop in temperatures and overall cooling of climate and the onset of glacial-interglacial climatic cycles. The cooling did not occur gradually, but in "steps", with intervals of sudden change, alternating with stable intervals. The Mediterranean is particularly sensitive to the record of astronomically induced oscillations in climate. This has already been extensively studied here. However, the Gulf of Lions enables us to link these oscillations to their effect on sea level and the erosion/sedimentation behavior of sedimentary systems.

- Except during the Messinian Event, the Mediterranean 


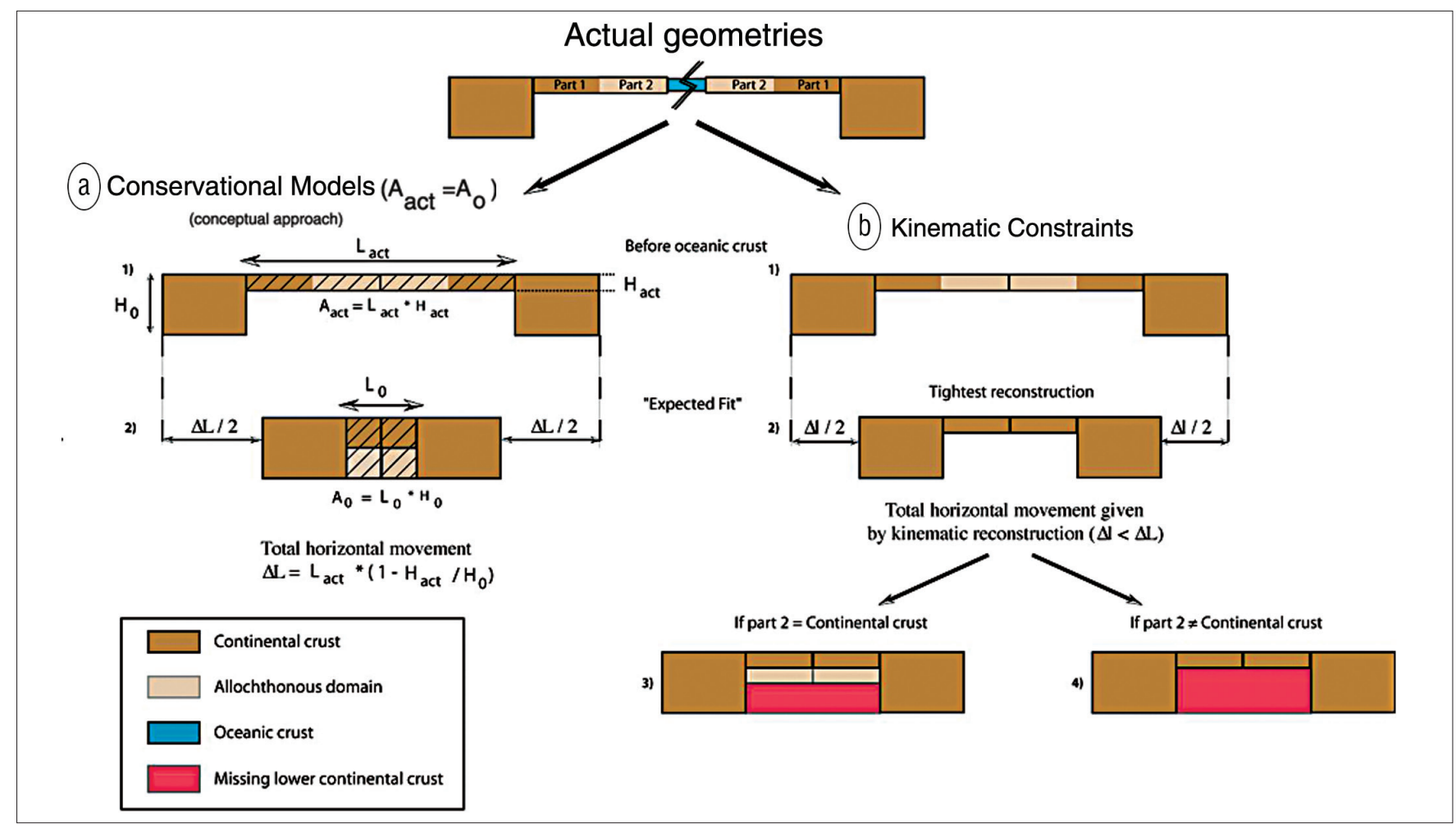

Figure 1. Conceptual versus kinematic approaches to explain the continental thinning process. At the top are simplified geometries of a system of conjugate margins, drawn after the conjugate Angolan and Espirito Santo (Brazil) continental passive margins. (a) Conceptual approach (conservational model). The present-day cross-sectional area of continental crust is intrinsically strictly equal to the initial area, the continental crust thinning process can be converted into horizontal movement. (b) Kinematic constraints. The horizontal movement is given by precise kinematic reconstruction. A wide, thinned, basin remains in this case. The allochthonous domains (part 2) of each margin overlap each other and are not shown on Figure 2b. The quantity of "missing" lower continental crust depends on the nature (lower continental or not) of the allochthonous domain. (After Aslanian and Moulin, 2012.)

Sea has been connected to the global ocean. The shelf and slope of the Gulf of Lions have recorded in great detail the successive glacio-eustatic fluctuations with a reconstruction of paleoshoreline positions. This has been extensively studied for the relative sea-level highstands and lowstands of the last 500,000 years confirmed by scientific drilling on the shelf. This approach needs to be extended back in time. Further detailed paleobathymetric markers, such as those of the Messinian surface or Pliocene-Quaternary shorelines, will provide markers with a precision never reached before to reconstruct paleogeographies (and also sea-level changes) and to better constrain the evolution of the subsidence of the margin.

- The margin presents the final sink for sediments coming from the second largest river in the Mediterranean region, the Rhône. Its drainage basin responds to climate change; for example the influence of mountain glaciers over the Alps during the Pliocene and Quaternary can be compared to periods without glaciers (Miocene and Messinian periods). This influence has never been quantified on a large time scale. Erosion/ sedimentation balance in this closed basin will provide answers to the question of the variability of sedimentary fluxes.

- The large shelf and the low continental slope gradient in the Gulf of Lions provide ideal conditions for observing and thus understanding the MessinianEvent. Here, we can measure the amount of subaerial erosion on the shelf, observe mark- ers of marine transgression on the slope and at the toe of the slope and map the succession of detritic units and their lateral seaward evolution and correlation to the evaporites. In the Gulf of Lions, the deep basin is the only area providing a full record of evaporite deposits. It is also in the eastern Mediterranean Sea that the markers of the history of MediterraneanAtlantic connections are the most direct and complete.

- The Gulf of Lions is the only place in the world where we can evaluate the effect of the magnitude of sea-level variations on the sedimentary system and on sediments budgets with amplitudes varying from $1500-\mathrm{m}$ fall and rise to $50-\mathrm{m}$ fall and rise. Because the western Mediterranean is a closed system, sediments are not "lost" and therefore one could have access to a real "source to sink" system quantifying sediment fluxes.

- Finally, thanks to an exceptionally large quantity of data (seismic profiles of different resolution, cores, drillings) coming from both industry and academia, the Gulf of Lions appears to be the very place to address fundamental questions about passive margins, paleo-climate, sea level and Messinian Salinity Crisis, and the deep biosphere and fully integrate results of ultradeep drilling. Intensive work (seismic interpretation, 3D mapping) has already been performed by French academic teams (universities, CNRS, IFREMER, BRGM, IFP) with industry support (TOTAL) as part of the French GDR Marges and Actions Marges programs, (http://gdrmarges.lgs.jussieu. fr; http://www.actionsmarges.univ-rennes1.fri). 


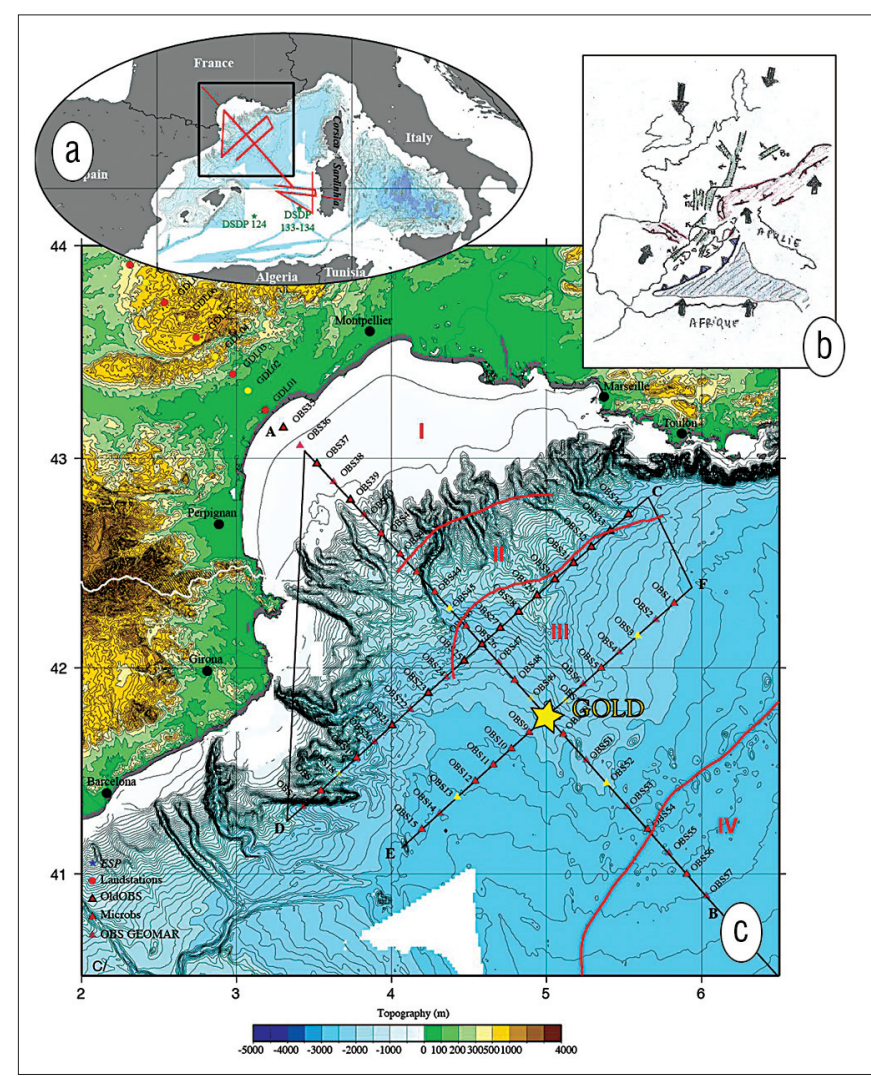

Figure 2. The extent of the Sardinia experiment is indicated by the red lines in (a) and the black lines with red and yellow triangles in (c). The location of the GOLD project in the Gulf of Lions is indicated by the yellow star. The NW-SE profile was extended on land (red and yellow circles). The red lines in (c) represent the limits of the different crustal domains which are indicated by red Roman numerals (for more details see text). Domain I represents a 20-km thick continental crust; domain II, the necking zone; domain III the transitional crust; and domain IV, the oceanic domain. (b) Geodynamic context before the opening of the Liguro-Provençal basin, in a back-arc position and at the southern end of the intra-European rift system.

\section{Geodynamic setting}

The Liguro-Provencal Basin reveals a structure and evolution corresponding to a pair of rifted margins formed by the rupture and counterclockwise rotation of the Corsica-Sardinian microcontinent with respect to the Iberian-European plate from the end of Eocene (Priabonian, 33.7 Ma), in a general context of collision between Africa and Europe (Olivet et al., 1996). The opening took place at the southern end of the intra-European rift system, in a back-arc situation, in response to a southeast rollback of the slab of the African plate subducting beneath the European plate during an extensional phase (Figure 2c). This rotation of the Corsica-Sardinian microcontinent resulted in the emplacement of oceanic crust, starting in the Late Aquitanian (23-19 Ma) and ending in the Langhian (about $15 \mathrm{Ma}$ ). Although rifting in back-arc basins might differ in some points from cratonic rifting, the mechanisms of thinning of continental crust can be expected to remain similar.

Several domains can be identified in the Liguro-Provençal Basin based on gravity, magnetic, reflection and wide-angle seismic data (Figure 2 for the Gulf of Lions side). Domain

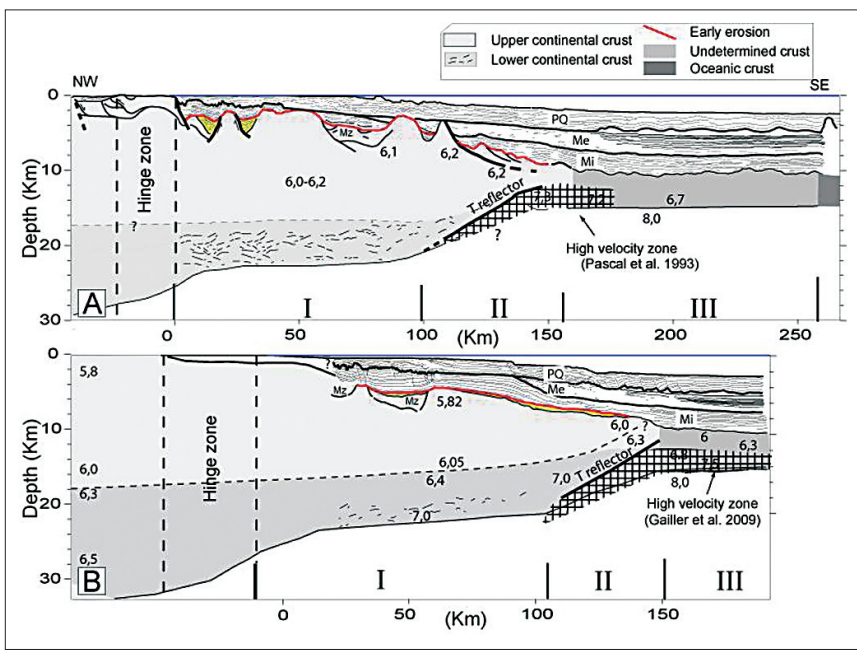

Figure 3. ECORS NW-SE and Sardinia 1 profile showing the thickness of Miocene and Pliocene Quaternary sequences, separated by the Messinian unconformity. Note the presence of a strong reflector, called the $T$ reflector, the high-velocity zone and the subaerial erosion reflector (red line) recorded before the first Miocene sediment. Roman numerals represent the different domains shown in Figure 2. (After Bache et al., 2010, and modified with results from Gailler et al., 2009.)

I represents a $20-\mathrm{km}$ thick continental crust; domain II the necking zone; domain III the intermediate crust; and domain IV the oceanic domain. Both ECORS-CROP and the Sardinia 1 reflection seismic profiles show the existence of a prominent landward-dipping reflector in the crust at the southeastern limit of the continental slope and called the $T$ reflector (Figure 3). Both images show a wide zone of high velocities southeastward of this reflector. These high velocities could be the expression of flowing lower continental crust underplated and intruded by partial melt, or representing serpentinized peridotite material exhumed during the initial opening of the basin. Based on these findings, an opening along a lithospheric detachment fault (possibly represented by the $\mathrm{T}$ reflector) has been proposed for the basin with the Sardinia margin representing the upper crustal plate, with exhumation of the mantle or lower crustal material occurring on the Gulf of Lions side. But the lack of deep crustal seismic data from the Sardinia margin has until now prevented testing this hypothesis and thus assessing the asymmetry of the system.

\section{Sardinia seismic experiment}

Wide-angle seismic data can be used to constrain the crustal geometry, determine the degree of symmetry of rift structures and hence answer fundamental questions concerning the mechanisms of rifting. During the Sardinia seismic survey conducted by Ifremer on the French $R / V$ L'Atalante, six coincident wide-angle refraction and multichannel reflection seismic (MCS) profiles, as well as CHIRP and bathymetric data were acquired. Three of the wide-angle seismic profiles are in the Gulf of Lions area and three on the conjugate margin offshore Sardinia. The main aims of the Sardinia wideangle seismic cruise were to image continuously the deep crustal structure of this conjugate margin pair, in order to 


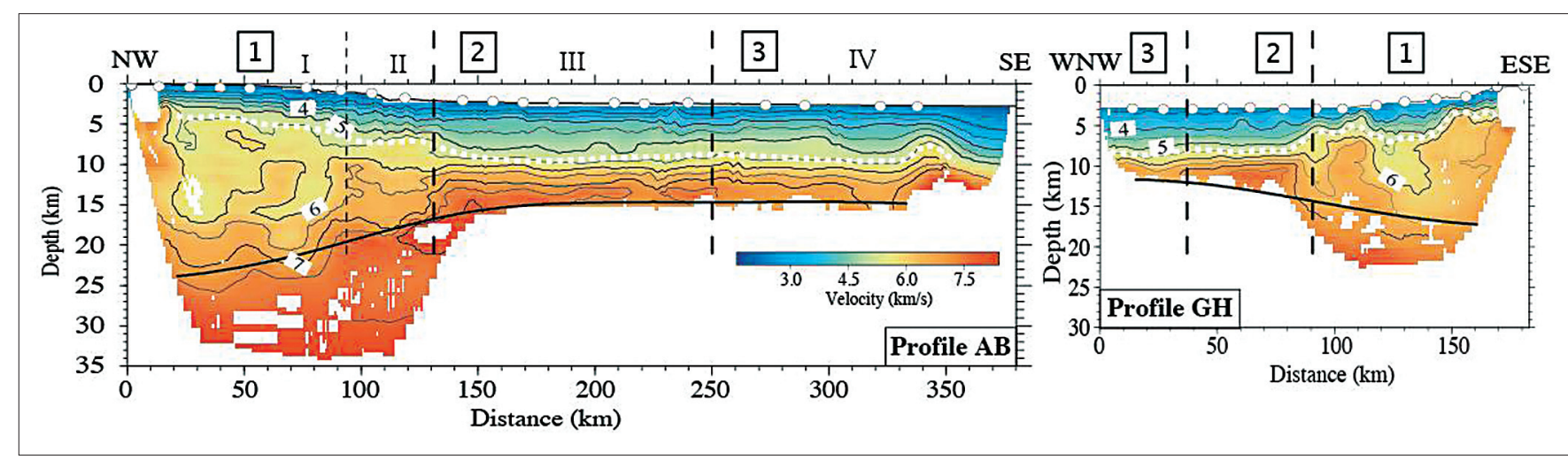

Figure 4. Final velocity models from tomographic inversion of first arrivals and one reflected phase (PmP). White circles $=$ OBS/OBH locations. Solid black line $=$ location of the Moho interface inverted from PmP arrivals. White dashed line = approximate location of the top of the crust, based on previous work from ESP and wide-angle modeling. See text for the definition of the three different regions. (Adapted from Gailler et al., 2009.)

verify the existence of a high-velocity zone on the Sardinia margin and to constrain the nature of the ocean-continent transition zone.

First results based on tomographic modeling of the two main conjugate profiles of this experiment showed similar seismic velocities on both sides, including an area characterized by high velocities in the lower crust. However, these zones are not of equal size.

Along both profiles, the resulting $2 \mathrm{D}$ velocity models show a similar evolution of the long-wavelength crustal velocity structures from the continental platform to the deep basin. Three different regions can be distinguished on these models (Figure 4).

- In Region 1, which corresponds to domains I and II (Figures 2 and 3), the Moho depth reaches $24 \mathrm{~km}$ in its inboard part and decreases progressively to $18 \mathrm{~km}$ in its distal part (130 $\mathrm{km}$ distance). This implies a thinning of the crust from 22 to $12 \mathrm{~km}$. This crust is characterized by low velocities and a very low vertical velocity gradient. The upper mantle velocity is also low, confirming the previous observation on the ECORS profile. A high-velocity zone, which is imaged on both margins of the basin might correspond to lower crustal material or a mixture of serpentinized upper mantle material with lower crustal material. The existence of this zone on both sides of the margin does not support a hypothesis of a simple shear-style opening along a lithospheric detachment fault. Some of the observed asymmetry may be due to the opening as a back-arc basin.

- Region 2 (domain III) is interpreted to be the continentocean transition zone, as the crustal velocity structure is not typical of neither continental nor oceanic crust. Its thickness is about $6 \mathrm{~km}$.

- The crust in Region 3 (domain IV), with a thickness of only $5 \mathrm{~km}$, has seismic velocities and vertical velocity gradients which are typical of oceanic crust, with the upper layer showing a high-velocity gradient (layer 2) and a second layer with a lower-velocity gradient (layer 3 ). The transition to Region 3 might occur over a distance of $20-30 \mathrm{~km}$ probably corresponding to the onset of sea-floor spreading.
High velocities found in the lower crust have been interpreted in different ways, such as: (a) exhumed mantle material; (b) highly thinned continental or oceanic crust overlying serpentinized mantle; and (c) exhumed lower crust or a mixture of lower crustal and upper mantle material

The high velocities found in the lower crust along the margin of the northwestern Mediterranean Basin (Figures 3 and 4) have been associated to mantle material exhumed during the initial opening of the basin and serpentinized by fluid flow through faults in the crust. In this case the reflections identified in OBS records correspond to the base of the serpentinization front, as it has been observed on the Iberian and Canadian margins, where they produce weak amplitude arrivals compared to the phases corresponding to a reflection between lower crust and upper mantle material $(\mathrm{PmP})$ on the same profile. In our OBS records, PmP arrivals show the same amplitude in Regions 2 and 3. This result does not clearly support an origin from serpentinized mantle material only (Figures 4 and 5). Highly thinned continental crust or thin oceanic crust overlying serpentinized mantle material is proposed on magma-poor margins. This crustal geometry would produce a PmP reflection above the serpentinized mantle layer and possibly a second reflection from the serpentinization front, which is not supported by our data, where the single PmP reflection can clearly be attributed to the base of the high-velocity zone (Figure 5).

The last possibility, namely exhumed lower crustal material or a mixture of lower crustal and upper mantle material, would produce one reflection with amplitude similar to that of a "normal" PmP reflection. This last interpretation is in good agreement with our data.

\section{Ground truth experiment: The GOLD project}

The aim of the GOLD project (Gulf Of Lions Drilling) is to conduct the first ever deep drilling in the Gulf of Lions, offshore France. The planned drill hole, in water depths of 2400 $\mathrm{m}$ at the toe of the slope, will penetrate $6.2 \mathrm{~km}$ of sediments deposited during the last $23 \mathrm{Ma}$ years. The 1-km thick Messinian salt layer requires the use of a modern drillship equipped with the latest technology in order to go through this layer that 
has never been drilled anywhere in the Western Mediterranean Sea. The GOLD project intends to bring together a large range of marine science disciplines (geology, microbiology, geochemistry, geophysics, biology, etc.) as well as engineering sciences (instrumentation, signal processing, etc.).

The major challenges of this drilling project can be grouped into several major scientific, social and economic themes:

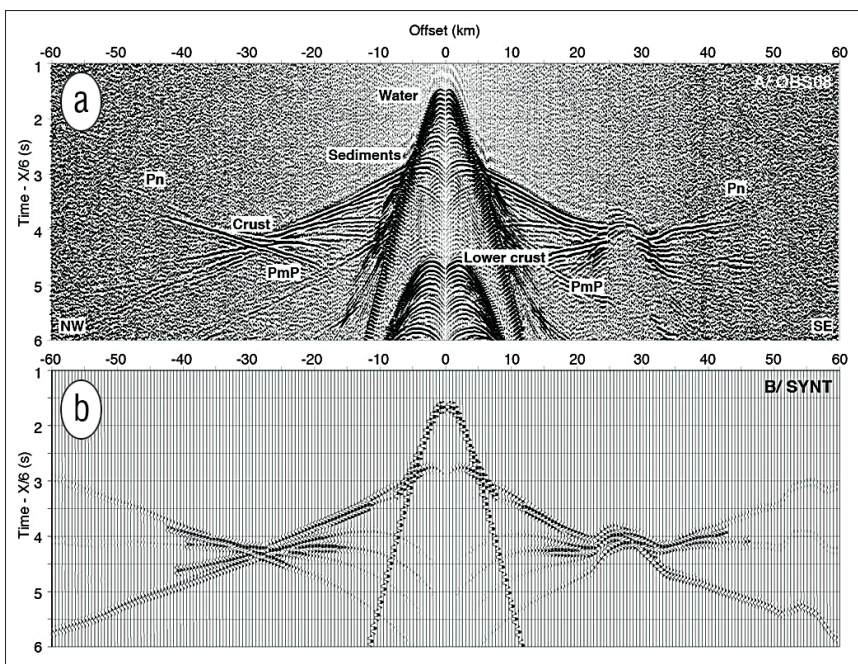

Figure 5. (a) Band pass-filtered $(5-20 \mathrm{~Hz})$ data from $O B S 8$ on profile $A B$, of the GOLD drilling proposal. The data are gain-adjusted according to the offset and reduced to velocity of $6 \mathrm{~km} / \mathrm{s}$. (b) Synthetic seismograms calculated for the same station using the asymptotic approach of ray theory. The synthetic seismograms are calculated every $500 \mathrm{~m}$, with a sampling rate of $120 \mathrm{~Hz}$, obtained by convolution of the impulse response with a 29-point low-pass Ricker wavelet. (From Moulin et al. submitted to Geophysical Journal International.)
1) Geodynamic, thermal structure and margin formation. Scientific drilling into the deep-water part of a continental margin to study the paleoenvironment of the syn- and post-rift deposits is still not common. Only a few continental margins have been drilled in order to reconstruct the geodynamic history of that margin. However, none of these deep-water drillings were performed in a relatively young basin formed in a back-arc extensional context. This information is needed to understand the thinning of the continental crust, the formation of the passive margins and the continental basins. What is the nature of the crust in the intermediate domain? In what kind of environment are the first sediments deposited? The GOLD drilling will offer the ground truth necessary to constrain models of margin formation and subsidence. Obviously, many outcomes are expected for hydrocarbon exploration efforts in the same general area.

2) Climate and sea-level changes. The Gulf of Lions is a unique place to study exceptionally well-preserved sedimentary archives. The quantity of sediments deposited is in direct relation with the existence of the northern hemisphere ice sheet, and its variations in size and thickness. These variations are related to climate changes and therefore we can document glacioeustatic cycles for the last 500,000 years in the sediments. This has been demonstrated using a dense grid of seismic lines and validated by a well drilled on the shelf. The proposed deep-water drilling, with as much continuous coring as possible, would extend this type of results to the last 23 Ma.

3) Deep biosphere and the limits of life. What is the maximum depth where life exists? In what form does it exist at extreme depth? Today's maximum depth where signals of life have been proven is at about $1600 \mathrm{~m}$ below the sea floor, but this

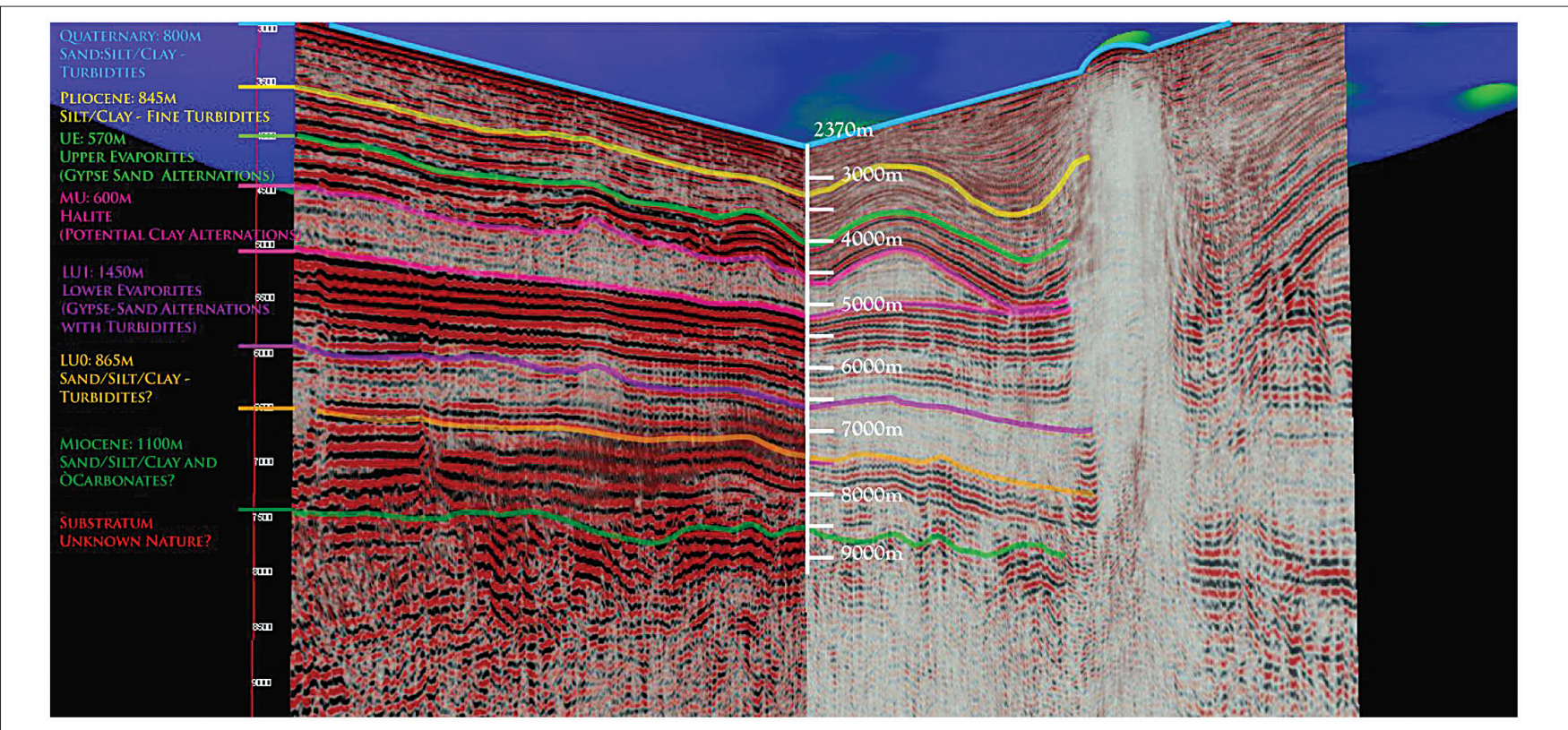

Figure 6. GOLD position on the two Sardinia crossing seismic profiles (see location on Figure 2). The multichannel seismic reflection data were acquired using a 4.5-km, 360-trace digital streamer and a tuned air-gun array of 8260 cubic inches. The shot interval was $60 \mathrm{~s}$ at an average speed of 5 knots, which translates to a shot spacing of about 140-150 m. The air-gun array consisted of 16 air guns with volumes ranging from 100 cubic inch G-guns to $16 \mathrm{~L}$ Bolt air guns, tuned to the first bubble and towed at depths of 18-28 m, in order to enhance low frequencies and ensure a good seismic penetration. The processing sequence included data geometry and binning, noise editing, time-variant band-pass fltering (6-20-48$62 \mathrm{~Hz}$ at sea floor to 2-12-24-32 $\mathrm{Hz} 4 \mathrm{~s}$ below sea floor), rms velocity analysis at 2.5-km spacing, and prestack Kirchhoff depth migration. 
is only the maximum reported depth where life has been sought. The proposed deep drilling $(7.7 \mathrm{~km})$ is a unique opportunity to constrain the physicochemical limits of life in extreme conditions in terms of salinity (in the salt layer), pressure and temperature (as we go deeper beneath the salt) and the composition, function and adaptation of microbial community (bacteria, archea, virus, microeucaryotes) in the deep-water Mediterranean Sea. The drilling provides a unique opportunity to better understand the beginning of life and its potential adaptation to extreme environments.

4) Extreme events. The nearly complete drying out of the Mediterranean Sea during the Messinian represents a unique hydrological, sedimentological and biological event in the Earth's history. This catastrophic crisis affects all the Mediterranean Sea with a sea-level fall of more than $1500 \mathrm{~m}$ inducing tremendous erosion on the continent and the shelf. Nearly $3000 \mathrm{~m}$ of evaporites and salt were also deposited in less than 500,000 years. DSDP and IODP wells only sampled the first few meters of this sequence. The deep-drilling will enable to sample the entire section and definitely test the contradictory models that exist for the process leading to the ultimate consequences of this crisis. Quantification of the mass movements involved will yield essential data set to study and understand the dynamic of underlying mantle (inducing isostatic adjustment).

5) Energy resources. Drilling below the salt would also bring key information to evaluate potential hydrocarbon resources in the Mediterranean Sea. The only known source rock is Messinian in age and is generally immature throughout most of the Algero-Provencal Basin. But sources rocks may also be located deeper and in older sequences (e.g., Aquitanian, Burdigalian, Langhian and Tortonian). The drill site also offers strong potential for geothermal energy. The concentration of lithium in the thick evaporites layer (up to $3000 \mathrm{~m}$ thick locally) should be evaluated as well as potential greenhouse gases storage in sandy reservoirs located below the Messinian salt layer, in the deep offshore of the Gulf of Lions in an area near major Mediterranean industrial centers (Marseille-Fos, Barcelona).

The GOLD project was submitted to the IODP Panel in April 2012. The primary goal is to sample most strata from Upper Evaporites-to-Miocene strata down to the basement and focus on extreme paleoenvironments, their geodynamic and deep biosphere consequences and to reach the transitional domain, whose nature is crucial to identifying and understanding passive margin genesis and evolution. The GOLD project will gather a unique group of expertise. A public-private consortium could be created with representatives from various international universities, public institutions (e.g., CNRS, Ifremer, IFP Energies Nouvelles, BRGM, CNR, CSIC), companies from the petroleum and any other industrial technical and/or environmental sectors.

\section{Conclusions}

Major efforts have been made to explore the conjugate Galician/Iberian and Newfoundland margins (legs 103, 149, 173, 210 and submitted ODP proposals 659, 692, and 740), which have improved our understanding of passive margin formation (e.g., the occurrence of limited magmatism despite the fact that extreme lithospheric thinning and exhumation of the mantle and lower continental crust occurred in the transition domain) as well as the asymmetry between the conjugate margins. Nevertheless, these discoveries mainly concern one end-member of conjugate passive margins system with strong continental lower crust (e.g., Huismans and Beaumont, 2011) and can hardly be applied to other margins. Furthermore, all propositions, all conceptual models must be placed on well-defined paleogeographic maps in order to test their consequences on global view to be validated. We need to avoid "conceptual kinematic models" presented on small map sketches as precise kinematic reconstruction can be only done with properly calculated Eulerian Poles (e.g., Aslanian and Moulin).

Combined wide-angle and reflection seismic data, precise kinematic reconstructions and detailed sedimentary studies in the Gulf of Lions-Sardinia conjugate margins system show that a large amount of lower crust is missing and that the thinning process, which evolves a high basement elevation until at least the breakup, seems to be depth dependent and mainly concerns the lower part of the continental crust. This evolution was already described in the central segment of the South Atlantic Ocean (Aslanian et al., 2009) in a different geodynamic context. TLE

\section{References}

Aslanian, D., M. Moulin, J.-L. Olivet, P. Unternehr, L. Matias, F. Bache, M. Rabineau, H. Nouzé, F. Klingelhoefer, I. Contrucci, and C. Labails, 2009, Brasilian and Angolan passive margins: the kinematic constraints: Tectonophysics, 468, 98-112. http://dx.doi. org/10.1016/j.tecto.2008.12.016

Aslanian, D., and M. Moulin, 2012. Paleogeographic consequences of conservational models in the South Atlantic Ocean, in W. U. Mohriak, A. Danforth, P.J. Post, D.E. Brown, G.C. Tari, M. Nemcok, and. S.T. Sinha, eds., Conjugate divergent margins: Geological Society, London, Special Publications, 369, http://dx.doi. org/10.1144/SP369.5.

Bache, F., J.-L. Olivet, C. Gorini, D. Aslanian, C. Labails, and M. Rabineau, 2010, Evolution of rifted continental margins: the case of the Gulf of Lions (Western Mediterranean Basin): Earth and Planetary Science Letters, 292, no. 3, 355-368, http://dx.doi.org/10.1016/j. epsl.2010.02.001.

Gailler, A., F. Klingelhoefer, J.-L. Olivet, and D. Aslanian, and the Sardinia Cruise Party, 2009, Crustal structure of a young margin pair: new results across the Liguro-Provencal Basin from wide-angle seismic tomography: Earth and Planetary Science Letters, 286, nos. 1-2, 333-345, http://dx.doi.org/10.1016/j.epsl.2009.07.001.

Huismans, R. S., and C. Beaumont, 2011, Depth-dependent extension, two-stage breakup and cratonic underplating at rifted margins: Nature, 473, no. 7345, 74-78, http://dx.doi.org/10.1038/nature09988. PubMed

McKenzie, D., 1978, Some remarks on the development of sedimentary basins: Earth and Planetary Science Letters, 40, no. 1, 25-32, http:// dx.doi.org/10.1016/0012-821X(78)90071-7.

Wernicke, B., 1985, Uniform sense normal simple shear of continental lithosphere: Canadian Journal of Earth Sciences, 22, no. 1, 108-125, http://dx.doi.org/10.1139/e85-009.

Corresponding author: aslanian@ifremer.fr 